CORRECTION

\title{
Correction: Restoring oysters to urban estuaries: Redefining habitat quality for eastern oyster performance near New York City
}

\author{
Katherine McFarland, Matthew P. Hare
}

The following information is missing from the Funding statement: This study was also supported by the New York Sea Grant project R/XG-22.

\section{Reference}

1. McFarland K, Hare MP (2018) Restoring oysters to urban estuaries: Redefining habitat quality for eastern oyster performance near New York City. PLoS ONE 13(11): e0207368. https://doi.org/10.1371/ journal.pone.0207368 PMID: 30444890

\section{G OPENACCESS}

Citation: McFarland K, Hare MP (2019) Correction: Restoring oysters to urban estuaries: Redefining habitat quality for eastern oyster performance near New York City. PLoS ONE 14(6): e0218535. https://doi.org/10.1371/journal.pone.0218535

Published: June 13, 2019

Copyright: @ 2019 McFarland, Hare. This is an open access article distributed under the terms of the Creative Commons Attribution License, which permits unrestricted use, distribution, and reproduction in any medium, provided the original author and source are credited. 